\title{
BEHAVIOURAL DIFFICULTIES: CHILDREN'S POINT OF VIEW
}

\author{
Algirdas Alisauskas \\ Siauliai University, Lithuania
}

\begin{abstract}
The author aimed at analysing the satisfaction with a school and education of primary school children, having behavioural problems, as well as to disclose the character and causes of their experienced difficulties, and describe their anxieties due to inappropriate behaviour. The structured interviews with children have been applied. Children had an opportunity to add their comments to certain question. It was found that the controversial approach towards the school is common for those children who experience behavioural difficulties. In the school the need of children to communicate with their peers is satisfied, however they are not satisfied within the requirements of education as well as with the conflict relationships with other students in a school. Children feel concern about their inappropriate behaviour, and experience anxiety and tension. However, they used to blame themselves because of inappropriate behaviour at school. Teachers are not enough focused on the support to a child, but usually shifts the responsibility on him or her.
\end{abstract}

Keywords: anxiety, behavioural difficulties, satisfaction with a school.

\section{Introduction}

The research problem and its relevance. Teachers in the educational practice usually encounter not behavioural and emotional disorders but behavioural difficulties, which manifest themselves by inappropriate, unacceptable behaviour in certain situations. Dreikurs (Dreikurs et al., 1982) described four goals of misbehaviour (attention getting, seeking power, seeking revenge and retreat, and displaying helplessness). These goals are related to the child's inappropriate behaviour in order to secure a "special" position for himself / herself.

Researches on children with behavioural and / or emotional problems disclose different attitudes to these children, educators' different activity strategies. In some cases the characteristics and reasons of the child's disorder or misbehaviour are emphasised, strategies are applied in order to cope with children's inappropriate behaviour (Delfos, 2004; Hampton, Hess - Rice, 2004; Samašonok, Gudonis, Juodraitis, 2010, etc.). Researchers note that pupils' misbehaviour is often treated as the child's individual problem, context-oriented approaches are rare (Evans, Haarden, Thomas, 2004; Davis, Florian, 2004, etc.). Special learning environments for prevention or control of behavioural and 
emotional disorders are rarely created (Mooij, Smeets, 2009, etc.). The systemic approach is characterised by the analysis of the problem and ways of its solution through interactions of children with behavioural and / or emotional problems with other participants of education and through improvement of these interactions (Evans, Haarden, Thomas, 2004; Thacker, Strudwick, Babbedge, 2002, etc.). Researchers (Geležinienè, Ruškus, Balčiūnas, 2008) notice that in the educational process the pupil with behavioural and emotional difficulties encounters different and little coherent activities of various teachers, ranging from orientation to constructive interactions and positive behaviour to construction of social isolation, stigmatization or even exclusion.

Studies attempt to typologize teacher activities educating children with behavioural and emotional disorders (Geležinienè, Ruškus, Balčiūnas, 2008, etc.), overview strategies of effective education of these children (Davis, Florian, 2004; Dervinytė - Bongarzoni, 2008; Evans, Haarden, Thomas, 2004; Gečienè, 2008; Thacker, Strudwick, Babbedge, 2002, etc.).

Documents often do not record children's behaviour and / or the emotional disorder, because parents do not address doctors, and the conclusion about the disorder can be made and documented only by a doctor (the child psychiatrist). Information provided by educators about pupils with behavioural and / or emotional disorders is controversial (Ališauskas et al., 2011). Educators state that solving problems of misbehaviour, they choose positive behaviour management techniques; however, every second surveyed educator has segregated attitudes towards children with behavioural problems and seeks to delegate the responsibility for inappropriate behaviour for the child (Ališauskas, Šimkienè 2013). As evidenced by research publications, researches on this topic most often view this problem from the standpoint of educators or specialists (special educators, psychologists, social educators, etc.). There is a lack of researches, where research participants would be the very children experiencing behavioural and / or communication difficulties and where it would be sought to analyse the problem from "inside", from the children's standpoint. This witnesses novelty and relevance of the research. This research ${ }^{1}$ analyzes problems of pupils with behavioural disorders and / or difficulties, not differentiating them strictly by belonging to one or another group of disorders or difficulties.

The research aim: to identify the attitude of children with behavioural problems to experienced difficulties.

The object of the research: self-feeling of children with behavioural problems (the type of experiences).

\footnotetext{
${ }^{1}$ The interview was conducted and data were collected by G. Šimkienè
} 
Research objectives:

1. To find out satisfaction with school and learning process of pupils with behavioural problems;

2. To disclose the character and reasons of difficulties arising for children;

3. To describe the child's experiences due to inappropriate behaviour and failures.

Research participants: pupils with behavioural and communication difficulties $(\mathrm{N}=12)$ learning in primary classes of the general education school.

Research methods: a structured interview with freely formulated answers. The aim of the interview was to find out satisfaction with school, difficulties arising in the learning process and communication of the pupil with behavioural difficulties and children's emotional experiences.

\section{Interview Results and Discussion}

\section{Pupils' satisfaction with school and the learning process}

The attitude of pupils with behavioural and communication difficulties to school is controversial: on one hand, they like school because here they can meet the need of communication with their peers; however, the teaching process poses numerous difficulties for them. The ratio of pupils whose statements witness satisfaction or dissatisfaction with school is similar (11:15). The majority of pupils, who participated in the interview, like going to school, because here they meet friends, play, and communicate: I like to go to school because here I meet my friends, we exchange stickers; I mostly like to go to school because I meet my classmates and I can play with them; yes, because here I find new friends; to meet friends, play. Interviewed pupils said that they had friends at school: I have very many friends and get along with them; all classmates are my friends, but I get along with boys better. Relationships with friends are quite changeable, depending on the mood: I have friends, we get on, but sometimes we fight because they annoy me, but I do not give up and defend myself, etc. During breaks, pupils enjoy engaging in agile and active activities: play with friends, run in the corridors, to catch friends; romp, compete with classmates, chase, etc. A share of pupils state they like learning or engaging in some extracurricular activities: I like it here because I can learn here; solve maths and attend the dance club, etc. Pupils who stated that they liked going to school, naming difficulties arising in the lessons, mentioned fewer difficulties than those who liked going to school only because they meet their friends there. Teachers also positively spoke about those pupils and mentioned that behavioural difficulties were arising to them not constantly. Speaking about their favourite lessons, pupils often indicate that their favourite lesson is 
physical education: I like physical education most because then we play the square or other games; because I really like to do sports, etc. Describing what they dislike at school, pupils named reasons of two kinds. The first is dissatisfaction with the educational process (or a certain lesson): that we need to be at school long; I don't like lessons because we need to learn a lot and quickly; because I do badly and I get bad marks; I don't like the English language, because you have to learn a lot of words, you also have to write a lot, and while writing I make mistakes; I can't keep up with what the teacher tells to do in the lessons; I don't like to go when we write tests or when you have to do a lot of homework; when you have to be at school a long time, etc. Most disliked lessons are mathematics and the Lithuanian language. According to pupils, they dislike these lessons not only because it is difficult to understand teaching materials but also because they have to stay after the lessons, do the tasks anew, do additional assignments, etc.

Another reason of unfavourable attitude to school is conflicts in relationships with other pupils at school: I most of all dislike when the older ones annoy; I most dislike that other kids beat me, etc.

\section{Pupils' experienced teaching and learning difficulties and their reasons}

Pupils with behavioural problems indicate that they experience various learning difficulties. Pupils experience learning difficulties in various learning areas: more often, in reading and writing, less often, in physical education, technologies and other lessons. The type of pupils' experienced difficulties is described in Table 1.

Prevailing difficulties are caused by the lack of attention and activity organization hindrances. During the lessons, pupils encounter many difficulties in activities requiring longer concentration, consistency, doing long and monotonous assignments. Children's experienced difficulties memorising and / or understanding assignments also hinder the learning process. This type of difficulties occurs two times less often than the ones caused by the lack of attention and activity organization. In case of difficulties, pupils usually receive teachers' assistance: during the lesson the teacher helps, she repeatedly explains what is not clear; I receive assistance from the teacher, she explains to me, helps what I don't understand; the teacher checks how I do the task, explains and then it becomes clear; the teacher comes up and explains or tells to do another, easier task; when the teacher repeatedly explains, it becomes clearer." Pupils state that the teacher's assistance is useful for them. They feel that the teacher sincerely wants to help them, understand them, shows goodwill. In such cases, the very pupil also tries to behave reservedly, more respectfully. 
Proceedings of the International Scientific Conference. Volume III, May $27^{\text {th }}-28^{\text {th }}$, 2016. 15-22

Table 1 Character of Learning Difficulties

\begin{tabular}{|c|c|c|}
\hline $\begin{array}{l}\text { Character of } \\
\text { difficulties }\end{array}$ & Examples of statements & $\begin{array}{l}\text { No. of } \\
\text { statements }\end{array}$ \\
\hline $\begin{array}{l}\text { Difficulties of } \\
\text { attention and } \\
\text { activity } \\
\text { organisation }\end{array}$ & $\begin{array}{l}\text { To write without mistakes. I hate the Lithuanian language, } \\
\text { because we have to write there and I make many mistakes, I } \\
\text { can't keep up with others, get lost, cross through in the } \\
\text { notebook, I make many mistakes. Dictations, spelling, } \\
\text { punctuation because I make many mistakes. I don't like } \\
\text { copying down from the book. I can't keep up with the } \\
\text { teacher's dictation. I can't write neatly, and when you have } \\
\text { to write a dictation, I write badly. I don't like when they ask } \\
\text { to draw something concrete, they don't allow me what I } \\
\text { want. I dislike sewing. I don't like when you have to fold } \\
\text { from paper because I fail. }\end{array}$ & 24 \\
\hline $\begin{array}{l}\text { Difficulties } \\
\text { memorising } \\
\text { and } \\
\text { understanding } \\
\text { teaching } \\
\text { materials }\end{array}$ & $\begin{array}{l}\text { I dislike dictations because I make many mistakes and have } \\
\text { forgotten the rules. To learn the rules, apply them. To learn } \\
\text { poems by heart, tell texts. I hate learning words. I dislike } \\
\text { solving problems because I have forgotten the } \\
\text { multiplication table. I can't learn words. I dislike } \\
\text { mathematics because I don't know the multiplication table. } \\
\text { I hate calculating, I don't understand a lot there. }\end{array}$ & 12 \\
\hline
\end{tabular}

\section{Children's experiences due to inappropriate behaviour}

Describing themselves, pupils attribute more positive than negative qualities to themselves. The ratio of indicated positive and negative qualities is 4:1 (43 positive and 12 negative qualities). Positive qualities dominated: consider themselves good (11 options), friendly (10 choices), intelligent (7 options), agile (6 options), cheerful (5 options), etc. Such pupils' selfassessment demonstrates that these pupils do not feel more inferior to others and do not give their learning and behavioural difficulties prominence. As to negative descriptions, the most common option is sad (6 options), pupils also mentioned such features as naughty (3), mean (2), ignoramus (1), etc.

Children's anxiety stems from failures in learning, hyperactivity, conflict relationships, etc. Interviews demonstrated that anxiety related to the child's behaviour or communication difficulties is encountered by all: the very children, their family members and teachers.

Pupils indicate: I am a little bit worried because I do not very well at school; I am very worried because often don't understand what I have to do in the lesson, and when I do, I must cross through everything and again do everything on my own anew; I am anxious, I would like not to ask anybody's help and do everything on my own, etc.

Pupils state that their family members are also worried about their behaviour: mom and dad are worried; mom always asks what homework is 
given, checks when I do it; parents keep saying to me, "be quieter", "don't get into trouble", "don't say anything to the teacher"; mother, she always asks me to collect my thoughts and listen to what the teacher says", etc. Parental concern manifests it self both by remarks, advice and assistance doing homework, explaining what the child has not understood at school. Four pupils state that they do not notice their inappropriate behaviour and do not worry about it. It is likely that these statements reflect not the true position of the child and his / her state but are a defensive reaction to experienced feelings. Two pupils think that it is the teacher who worries about their behaviour most and who mostly takes care of them: the teacher always asks me to learn and calms me. Two children state that their misbehaviour does not cause any concern to anyone.

In order to find out pupils' attitude to experienced behavioural problems and the way out of the situation, pupils and teachers were asked to complete the sentence "There would be no problems if ...".

The majority of pupils who took part in the research tend to look for reasons of behavioural and communication difficulties in themselves: if $I$ learned even more; if I didn't make mistakes writing; if I were braver; if I were able to concentrate during the lessons; if I did everything quicker, etc. Such pupils' answers show the attitude instilled by teachers and parents that the very child is guilty for difficulties arising to him / her. The minority of children think that they would avoid problems if they received assistance from parents, teachers, friends, if they were not separated from classmates and if other pupils treated them with respect.

Teachers, on the contrary, tend to see the problem and its solution in the very pupils, parents or other circumstances but not in their own activities. Teachers envisage the majority of problems in the very children: if he were polite, thought what he is doing; if the girl reacted to remarks because she is talented enough; if the child finally descended on the ground and grew; if began to hear what I am saying and not only wanted to learn but also learned; if at least made a small effort; if didn't dream in the lessons and if asked when something is not clear, asked, asked for help. Teachers would like to receive assistance from parents and the teacher's assistant; then, in their opinion, there would be no difficulties because solely teacher's efforts are insufficient: if parents gave more love for the child and he / she felt safe and loved; if parents took interest in the child, because solely the teacher's efforts are insufficient; if there were the teacher's assistant, etc. Although rarely, but some of teachers' statements reflected emphasis on exclusion of these pupils: if there were no such children at all; if A. were not in the classroom. According to these teachers, there would be no problems if such children were not present. Teachers' attitude towards children with behavioural and / or communication difficulties depends on the teacher's experience and competencies. The more the teacher has 
encountered practice of educating such children, the more often he / she finds suitable education methods and does not reject these pupils.

\section{Conclusions}

1. Pupils with behavioural difficulties are characterised by a controversial approach to school: at school they can meet the need for communication with their peers and acquire knowledge; however, their poor satisfaction with organized and regulated teaching process (or separate lessons) and conflict relationships with other pupils come to prominence.

2. Pupils' experienced difficulties manifest themselves in various areas of learning (more often in writing and calculating, more rarely in physical education, technologies, etc.); they are mostly determined by the lack of attention and activity organization, and more rarely, by the lack of memorising and understanding of teaching materials.

3. Children suffer due to their misbehaviour, experience anxiety and tension; mostly tend to blame themselves for arising problems; such pupils' approach could have been formed by educators and parents, constantly blaming the child and emphasizing arising difficulties.

4. At school pupils with behavioural and communication difficulties feel little satisfaction with the educational process and communication, while teachers insufficiently focus on assistance to the child and mostly tend to blame children for their misbehaviour. Communication between teachers and pupils with behavioural problems should be changing replacing disciplinary relationships with the emphasis on positive behaviour and assistance to the child.

\section{References}

Ališauskas, A., \& Šimkienė, G. (2013). Mokytojų patirtys, ugdant mokinius, turinčius elgesio ir/ar emociju problemu. Specialusis ugdymas, 1 (28), 51-61.

Ališauskas, A., Ališauskienė, S., Gerulaitis, D., Kaffemanienė, I., Melienė, R., \& Miltenienė, L. (2011). Specialiuju ugdymo(si) poreikiu tenkinimas: Lietuvos patirtis užsienio šaliu kontekste. Mokslo studija. Šiauliai. Všı̆ ŠU leidykla.

Davis, P., \& Florian, L. (2004). Teaching Strategies and Approaches for Pupils with Special Educational Needs: A Scoping Study. Queen's Printer.

Delfos, M. F. (2004). Children and behavioural problems: anxiety, aggression, depression and ADHD: a biopsychological model with guidelines for diagnostics and treatment. London: Jessica Kingsley.

Dervinytè-Bongarzoni, A. (2008). Pagalbos galimybès aktyvumo ir dèmesio sunkumu turintiems vaikams. Metodinès rekomendacijos mokyklų specialistams. Vilnius.

Dreikurs, R., \& Vicki Soltz (1995). Happy Children. A Challenge to Parents. Published by the Australian Council for Educational Research. Ltd, Acer. Melbourne. 
Dreikurs, R., Grunwald, B. B., \& Pepper, F. C. (1982). Maintaining sanity in the classroomclassroom management techniques. Harper \& Row.

Evans, J., Haarden, A., \& Thomas, J. (2004). What are effective strategies to support pupils with emotional and behavioural difficulties (EBD) in mainstream primary shools? Findings from a systematic review of research. Journal of research in special educational needs, 4 (1), 2-16.

Gečienè, J. (2008). (Red.) Hiperaktyviu mokiniu gebejimu ugdymas. Metodinè veikla mokytojo ir mokinio kompetencijoms ugdyti: iš mokytoju patirties. Pedagogu profesinès raidos centras. Vinius: Lietuvos Respublikos Švietimo ir mokslo ministerija Švietimo aprūpinimo centras.

Geležinienė, R., Ruškus, J., \& Balčiūnas, S. (2008). Mokytojų veiklų, ugdant elgesio ir emociju sutrikimų turinčius vaikus, tipologizavimas. Specialusis ugdymas, 2 (19), 45 58.

Hampton, S. S., \& Hess - Rice, E. K. (2003). Restructuring service delivery for students with emotional and behaviour disorders. In: F. E. Obiakor, C. A. Utley, A. F. Rotatori (Eds.) Effective education for learners with exceptionalities (pp. 119-128). Oxford, England: Elsevier Science/ UK, JAI Press.

Mooij, T., \& Smeets, E. (2009). Towards systemic support of pupils with emotional and behavioural disorders. International Journal of Inclusive Education, (13) 6, 597-616.l

Samašonok, K., Gudonis, V., \& Juodraitis, A. (2010). Institucinio ugdymo ir adaptyvaus elgesio modeliavimas. Monografija. Šiauliai: ŠUL.

Thacker, J., Strudwick, D., \& Babbedge, E. (2002). Educating children with emotional and behavioural difficulties. Inclusive practice in mainstream schools. London: Routledge. 